\title{
PENELITIAN TENTANG FORMATIO SPIRITUALITAS DAN KEPRIBADIAN DI RUMAH BINA KARYA ILLAHI MADIUN
}

\author{
Agustinus Wisnu Dewantara \\ STKIP Widya Yuwana \\ dewacm@widyayuwana.ac.id
}

\begin{abstract}
Rumah Bina Karya Illahi is a house (a kind of dormitory) that accommodates first-level. Rumah Bina organizes a lot of coaching as a basis for students to take further education. Students are active subjects of development, while regulations are only a means of assisting to practice responsibility and life discipline. As development subjects, students must learn to self-regulate, therefore, the foster home also trains students to be responsible for themselves. This research was conducted at the Divine Works Bina House during 2019 s.d. 2020 to measure the four focus areas of coaching (personal maturity, spirituality, study life, and humanities) associated with community rules and events as a means of formation in the foster home so far. The research was conducted by distributing questionnaires to all residents of the Bina House in the period 2019 s.d. 2020. The results showed that most of the students understood the importance of rules in living together, spiritual life, and community life in joint formation. There are number of students who experience formation at Rumah Bina. Rules in living together are needed to maintain orderly living together in Rumah Bina. Thankfully, the majority of respondents realized the importance of living together, the importance of spiritual events to foster their spirituality, and the need for community events to instill good habits. Orders, spiritual events, and community events are the foundation needed for joint formation.
\end{abstract}

Keywords: Rumah Bina, formation, spirituality, personality

\section{PENDAHULUAN}

Rumah Bina merupakan bagian integral dari STKIP Widya Yuwana Madiun, STKIP Widya Yuwana sendiri merupakan lembaga pendidikan tinggi keuskupan Surabaya yang didirikan sejak tahun 1959, untuk menghasilkan para Sarjana Strata Satu (S1) bidang pendidikan keagamaan Katolik. STKIP Widya Yuwana mempunyai Rumah Bina Karya Illahi yang berada dalam kompleks yang sama. Lembaga pendidikan tinggi ini didirikan oleh Keuskupan Surabaya untuk menghasilkan para Sarjana Strata Satu (S1) bidang pendidikan keagamaan 
Katolik. Hingga tahun 2018, lembaga pendidikan tinggi ini telah meluluskan 1.200 Sarjana Pendidikan Keagamaan Katolik. Hasil survei 2017 mengungkapkan bahwa $87 \%$ dari lulusan ini bekerja sebagai guru agama Katolik dan katekis di berbagai Keuskupan di seluruh Indonesia.

Jumlah mahasiswa aktif yang sedang belajar pada lembaga pendidikan tinggi saat ini berjumlah 165 orang dan berasal dari 21 Keuskupan di seluruh Indonesia. Mayoritas (70\%) dari total mahasiswa yang sedang belajar ini berasal dari keluarga dengan latar belakang ekonomi menengah ke bawah.

Lembaga pendidikan tinggi ini terus berusaha meningkatkan mutu pendidikannya dari waktu ke waktu agar semakin mampu menghasilkan lulusanlulusan yang bermutu tinggi dan siap mengabdikan ilmu pengetahuan dan keterampilan yang mereka miliki untuk kemajuan Gereja, masyarakat, dan bangsa Indonesia.

Rumah Bina Karya Illahi adalah rumah (semacam asrama) yang menampung mahasiswa tingkat I (Rumah Bina, 2018:2). Rumah Bina ini menyelenggarakan banyak pembinaan sebagai pendasaran bagi para mahasiswa untuk menempuh pendidikan selanjutnya. Perlu diketahui juga bahwa mayoritas (70\%) dari total mahasiswa yang sedang belajar berasal dari keluarga dengan latar belakang ekonomi menengah ke bawah. Pada awal tahun 2018, Rumah Bina Karya Illahi melaksanakan suatu program pembinaan baru. Para mahasiswa baru akan dididik dalam pembinaan integral dengan mencontoh pendidikan kader yang dilaksanakan di seminari.

\section{PEMBAHASAN}

\subsection{Hakekat Rumah Bina}

Rumah bina hakekatnya adalah sebuah rumah (home), yang didalamnya ada satu komunitas hidup bersama. Jelaslah bahwa hidup bersama di sini bukan seperti di hotel, asrama, atau tempat kost. Hidup bersama di sini mempunyai banyak persamaan dengan hidup dalam keluarga, karena itu banyak hal yang dihayati dalam keluarga juga dihayati di sini, misalnya: tanggungjawab, persaudaraan, kasih, rasa memiliki, dan sebagainya (Rumah Bina, 2018:3). Hubungan persaudaraan tidak didasarkan pada hubungan darah, tetapi pada hubungan rohani, yaitu kita ingin melaksanakan kehendak Allah, sehingga ciri khasnya adalah: satu iman akan Kristus, satu panggilan menjadi calon pewarta sabda, dan satu komunitas. Kesatuan tersebut membawa kita sehati dan seperasaan yang merupakan ciri khas dari setiap keluarga. Kemanunggalan hati ini diwujudkan dengan rasa saling percaya, menghargai, memperkaya, dan menghormati (Rumah Bina 2018:3).

Ada beberapa cara yang merupakan "perayaan keluarga” yang bertujuan membantu untuk mengungkapkan dan mengembangkan persaudaraan antara kita, 
yaitu: berdoa, makan, olahraga, rekreasi, dan aneka pendalaman bersama. Oleh karenanya, semua anggota harus hadir sebagai bentuk perayaan keluarga. Sebagai anggota keluarga, semua harus bertanggungjawab atas semua hal yang ada di rumah bina, misalnya: kebersihan dan pemeliharaan barang. Keikutsertaan, tanggungjawab, rasa memiliki (handarbeni) akan mewujudkan persekutuan yang akrab dan hangat. Sikap ini menjadi bekal bagi tiap anggota untuk menjadi insan persekutuan sebagai pewarta dan pelayan nantinya (Rumah Bina 2018:3).

Rumah bina adalah rumah pembinaan bagi para calon pewarta Sabda Allah. Para pewarta adalah insan Allah demi kasih pastoral, maka semua acara harus membantu menjadi insan Allah dan lebih dekat denganNya (Rumah Bina 2018:4). Sarana eksplisit dari ini tentu adalah doa. Maka, rumah bina harus mewujudkan diri sebagai komunitas doa. Doa inilah yang menjadi bahan bakar bagi pastoral. Hidup bersama sebagai keluarga dan usaha membatinkan nilai-nilai perlu ditunjang oleh peraturan untuk menciptakan kenyamanan bersama. Sebagaimana keluarga pada umumnya mempunyai aturan hidup bersama, maka rumah bina juga mempunyai aturan yang harus dilaksanakan bersama pula, Mengapa? Karena rumah ini bukan sekedar rumah, tetapi rumah bina yang ditujukan untuk membina hidup bersama. Mengenai hal ini berlaku prinsip: “Keep the rule, and the rule will keep you." (Rumah Bina 2018:4).

Para mahasiswa adalah subyek bina yang aktif, sedangkan perturan hanyalah sarana bantu untuk melatih tanggungjawab dan kedisiplinan hidup (Dewantara, A. W, 2015:6). Sebagai subyek bina, para mahasiswa harus belajar mengatur diri, oleh karena itu, rumah bina juga melatih para mahasiswa untuk bertanggungjawab atas dirinya sendiri (terutama pada hari Kamis dan Minggu). Ada kalanya mentaati aturan, tetapi adakalanya juga harus mengatur diri sendiri.

Para mahasiswa juga diberi tanggungjawab untuk ikut serta secara aktif menentukan jalannya hidup komunitas dengan menjalankan tugasnya dalam fungsionaris. Para mahasiswa juga harus memperhatikan sopan santun dalam menggunakan barang milik bersama yang digunakan untuk kebutuhan bersama, misalnya: komputer, printer, kamar, kamar mandi, televisi, buku doa, dan lain sebagainya. Setiap hari rabu berlaku English Day, sehingga sedapat mungkin semua percakapan dilakukkan dengan menggunakan bahasa Inggris. Hal ini diperlukan sebagai pembekalan memasuki dunia akademik yang pasti bersentuhan dengan bahasa Inggris. Pembekalan bahasa Jawa untuk melakukan pastoral di stasi dilakukan pada hari Jumat. Sedapat mungkin dua hari tersebut menggunakan bahasa tersebut di atas, kecuali ada hal yang memang tidak memungkinkan untuk menggunakannya.

Saat-saat hening diperlukan dan harus diciptakan untuk mendukung kegiatan rohani, studi, istirahat, dan refleksi. Saat hening diperlukan agar para mahasiswa peka pada bimbingan Roh Kudus dan akan situasi orang lain yang 
membutuhkan keheningan ketika berdoa atau belajar (Rumah Bina 2018:5). Pada saat itu, mohon dihindari segala macam kegaduhan, baik yang berasal dari alat elektronik maupun dari kegiatan lain (seperti: berteriak, berlari, menutup pintu, dst).

Kerja (opera) merupakan acara komunitas yang berguna untuk menghargai pekerjaan tangan, mengembangkan solidaritas, menjaga kreativitas, melatih kerjasama, memupuk rasa ikut memiliki, dan mengembangkan tanggungjawab untuk memelihara kebersihan dan keindahan. Rekreasi adalah acara wajib komunitas untuk menyegarkan kembali (re-creation = mencipta kembali) dari kelelahan dan kepenatan tugas. Rekreasi juga berfungsi untuk menumbuhkan semangat persaudaraan dan cinta komunitas. Hendaknya segala sarana di ruang rekreasi (TV, alat permainan, alat musik, dan lain sebagainya) benar-benar dipandang sebagai sarana untuk menyegarkan diri, dan bukan tujuan yang bisa mengalahkan studi dan acara rohani (Rumah Bina 2018:3). Studi adalah kegiatan yang dilaksanakan untuk mengasah intelektualitas para mahasiswa sebagai insan akademik. Hendaknya, setiap mahasiswa menggunakan waktu studi secara bertangungjawab sehingga bisa tercapai prestasi yang setinggi-tingginya.

Subyek sasaran dari formatio Rumah Bina Karya Illahi adalah para mahasiswa semester satu (wajib). Di samping itu, Rumah Bina juga membuka diri bagi para mahasiswa semester berikutnya yang secara sukarela memilih tinggal di Rumah Bina. Mahasiswa adalah subjek pembinaan, maka orientasi dari gerak pembinaan adalah demi perkembangan para mahasiswa itu sendiri. Awalnya, para mahasiswa menempati rumah bina selama empat tahun (sejak angkatan 2014). Kebijakan tersebut kemudian berganti menjadi dua tahun wajib di rumah bina (sejak angkatan (2016). Tahun 2018 sampai dengan hari ini (dengan memperhatikan daya tampung), akhirnya ditetapkan bahwa kewajiban pembinaan di rumah bina hanya dikenakan pada tingkat 1 , tetapi dengan menerapkan model pembinaan yang lebih komprehensif.

\subsection{Kajian Teori}

Hidup rohani sering dikatakan sebagai spiritualitas, yang berasal dari kata Latin “spiritus” (Tondowidjojo, 2012:xv). McClelland dalam Masaong (2000:2) menegaskan bahwa kemampuan akademik atau prestasi kelulusan yang tinggi bukanlah faktor utama dalam kesuksesan seseorang. Ada faktor lain yang mendukung hal tersebut, yaitu kecerdasan spiritual (Dwilestari, A., \& Dewantara, 2019:30). Kecerdasan hidup rohani sangat penting dalam mengajak dan membimbing seseorang menjadi manusia yang asli dan otentik karena pada hakekatnya manusia juga mempunyai dimensi spiritual (Juna, M., \& Dewantara, 2018: 135). Dimensi spiritual inilah yang membuat hidup manusia menjadi seimbang dan terarah. Spiritualitas yang mendalam membuat seseorang lebih 
maksimal dalam mengoptimalkan seluruh kemampuan (kognitif, afektif, kecerdasan, emosi, dll) yang dimilikinya.

Pedoman Mahasiswa STKIP Widya Yuwana (2009:11) dalam pasal 30 ayat 7 menyebutkan bahwa mahasiswa dinyatakan lulus jika sudah dinyatakan lulus juga dalam pembinaan spiritualitas. Hal ini bisa dipahami karena STKIP Widya Yuwana mendidik para calon katekis dan guru agama Katolik yang harus mumpuni hidup rohaninya. Formatio di Rumah Bina adalah sarana untuk mengembangkan kemampuan rohani, dan kematangan pribadi para mahasiswa sebagai para calon pewarta Sabda Allah. Formatio Rumah Bina menajadi landasan yang diperlukan bagi efektifitas kecerdasan intelektual dan emosional. Pembinaan sipirtualitas berkaitan dengan kecerdasan jiwa yang bertumpu pada kearifan dan moralitas (Zohar dan Marshal, 2007:293).

Para mahasiswa diharapkan berkembang kepribadiannya secara utuh dari waktu ke waktu, bisa balajar mengenai cara membawakan diri dengan baik sebagai calon pewarta sabda, bertumbuh dalam kesopanan dan kesantunan, belajar bagaimana mendisiplinkan diri lewat keteraturan hidup yang ada di Rumah Bina, mendapat pendampingan pribadi jika mendapati masalah sehingga makin terbentuklah pribadi yang matang dalam (Rumah Bina, 2018:2). Para mahasiswa juga diharapkan untuk bertumbuh dalam hidup rohani dalam iman Katolik (Tarigan, 2015:35). Hidup doa, akrab dengan tradisi doa Gereja, pengolahan hidup rohani menjadi aspek penting yang hendak ditumbuhkan (Hardjana, 2005:66). Hal ini dilakukan dengan mewajibkan mahasiswa untuk mengikuti acara-acara rohani selama berada di Rumah Bina (misa, meditasi, rosario, lectio divina, rekoleksi, retret, ibadat, completorium, pendalaman Kitab Suci-APP, dll) (Rumah Bina, 2018:3). Para mahasiswa diharapkan bertumbuh sebagai manusia seutuhnya yang sekaligus memiliki penghargaan pada manusia lain. Mahasiswa diharapkan semakin menghargai teman dan memiliki semangat multikultural ketika berjumpa dengan rekan-rekan yang berbeda suku dan budaya (Dewantara, A. W., \& Permana, N. S. 2018:41). Semangat dan nilai gotong-royong juga amat ditanamkan sebagai nilai khas Indonesia (Dewantara, 2019:78).

\subsection{Penelitian Tentang Formatio di Rumah Bina Karya Illahi}

Penelitian ini dilakukan di Rumah Bina Karya Illahi selama tahun 2019 s.d. 2020 untuk mengukur keempat bidang fokus pembinaan tersebut (kematangan pribadi, spiritualitas, hidup studi, dan humaniora) dikaitkan dengan aturan dan acara komunitas sebagai sarana formatio di rumah bina selama ini. Penelitian dilakukan dengan cara menyebarkan angket kepada semua penghuni Rumah Bina dalam kurun waktu 2019 s.d. 2020. Daftar pertanyaan angket dan jawaban responden akan dilampirkan pada bagian lampiran. Responden terdiri dari berbagai angkatan dan aneka latar belakang, yang sebagian besar adalah 
mahasiswa tingkat I yang sedang menjalani tahun wajib bina selama tahun awal menjadi mahasiswa STKIP Widya Yuwana.

Mahasiswa selama tahun 2019 ada 64 orang, dan mahasiswa tahun 2020 ada 71 orang, sehingga secara keseluruhan ada 135 responden. Pertanyaan di kedua tahun itu sama. Angket tersebut memuat pertanyaan tertutup yang meminta jawaban sangat setuju, setuju, ragu-ragu, tidak setuju, dan sangat tidak setuju. Pertanyaan tertutup diajukan untuk mengetahui respon mahasiswa terhadap aturan atau tata hidup bersama, hidup rohani, dan acara komunitas. Pertanyaan terbuka diajukan untuk mengetahui usulan dan refleksi mahasiswa selama tinggal di rumah bina.

Dari keseluruhan responden (135), ada 3 responden yang tidak menjawab, sehingga dua ini dikategorikan sebagai tidak valid. Hal ini mengakibatkan hanya ada 132 jawaban yang terhitung valid. Jika masing-masing pertanyaan memuat empat item, maka di masing-masing pertanyaan itu ada 528 jawaban valid. Aspek yang mau diketahui adalah: tata hidup bersama, hidup rohani, dan acara komunitas. Masing-masing pertanyaan dan jawaban yang merupakan hasil penelitian akan ditampilkan dalam tabel berikut:

\section{Aspek Tata Aturan Hidup Bersama}

\begin{tabular}{|c|c|c|c|c|c|c|c|}
\hline A & No. & Pernyataan & $\begin{array}{l}\text { Sangat } \\
\text { Setuju }\end{array}$ & Setuju & $\begin{array}{c}\text { Ragu- } \\
\text { ragu }\end{array}$ & $\begin{array}{c}\text { Tidak } \\
\text { Setuju }\end{array}$ & $\begin{array}{c}\text { Sangat } \\
\text { Tidak } \\
\text { Setuju }\end{array}$ \\
\hline & 1 & $\begin{array}{llr}\text { Aturan hidup } & \text { yang } \\
\text { diterapkan di Rumah Bina } \\
\text { mendukung perkembangan } \\
\text { saya secara pribadi }\end{array}$ & 47 & 75 & 10 & 0 & 0 \\
\hline & 2 & $\begin{array}{l}\text { Saya lebih banyak menaati } \\
\text { aturan tersebut daripada } \\
\text { melanggarnya }\end{array}$ & 25 & 67 & 29 & 9 & 2 \\
\hline & 3 & $\begin{array}{llr}\text { Saya } & \text { menaati } & \text { aturan } \\
\text { tersebut } & \text { karena } & \text { kesadaran } \\
\text { pribadi } & & \\
\end{array}$ & 21 & 72 & 32 & 5 & 2 \\
\hline & 4 & $\begin{array}{lr}\begin{array}{l}\text { Saya menaati } \\
\text { tersebut }\end{array} & \text { karena } \\
\text { keterpaksaan } & \\
\end{array}$ & 2 & 13 & 37 & 52 & 28 \\
\hline & & Jumlah & 95 & 227 & 108 & 66 & 32 \\
\hline & & Total & \multicolumn{5}{|c|}{528} \\
\hline
\end{tabular}

Aspek Hidup Rohani

\begin{tabular}{|c|c|c|c|c|c|c|c|}
\hline B & No. & Pernyataan & $\begin{array}{c}\text { Sangat } \\
\text { Setuju }\end{array}$ & Setuju & $\begin{array}{c}\text { Ragu- } \\
\text { ragu }\end{array}$ & $\begin{array}{c}\text { Tidak } \\
\text { Setuju }\end{array}$ & $\begin{array}{c}\text { Sangat } \\
\text { Tidak } \\
\text { Setuju }\end{array}$ \\
\hline 1 & $\begin{array}{l}\text { Acara rohani di Rumah } \\
\text { Bina (meditasi, relaksasi, } \\
\text { becaaan rohani, Rosario, } \\
\text { lectio divina, misa, refleksi, } \\
\text { completorium, emaus,dll) } \\
\text { mendukung perkembangan }\end{array}$ & 64 & 66 & 1 & 1 & 0 \\
\hline
\end{tabular}




\begin{tabular}{|c|c|c|c|c|c|c|}
\hline & \multicolumn{2}{|l|}{ hidup rohani saya. } & & & & \\
\hline 2 & $\begin{array}{l}\text { Saya lebih banyak } \\
\text { mengikuti acara tersebut } \\
\text { daripada absen }\end{array}$ & 48 & 75 & 6 & 0 \\
\hline 3 & $\begin{array}{l}\text { Saya mengikuti acara rohani } \\
\text { tersebut karena kesadaran } \\
\text { pribadi }\end{array}$ & 32 & 76 & 21 & 3 & 0 \\
\hline 4 & $\begin{array}{l}\text { Saya mengikuti acara rohani } \\
\text { tersebut karena } \\
\text { keterpaksan }\end{array}$ & 1 & 9 & 17 & 57 & 48 \\
\hline & Jumlah & 145 & 226 & 45 & 64 & 48 \\
\hline
\end{tabular}

Aspek Acara Komunitas

\begin{tabular}{|c|c|c|c|c|c|c|c|}
\hline C & No. & Pernyataan & $\begin{array}{l}\text { Sangat } \\
\text { Setuju }\end{array}$ & Setuju & $\begin{array}{l}\text { Ragu- } \\
\text { ragu }\end{array}$ & $\begin{array}{l}\text { Tidak } \\
\text { Setuju }\end{array}$ & $\begin{array}{l}\text { Sangat } \\
\text { Tidak } \\
\text { Setuju }\end{array}$ \\
\hline & 1 & $\begin{array}{l}\text { Acara komunitas di Rumah } \\
\text { Bina (wicara, sidang } \\
\text { akademi, rekreasi, opera, } \\
\text { konferensi, dinamika } \\
\text { kelompok, paduan suara, } \\
\text { bahasa inggris, studi, dll) } \\
\text { mendukung perkembangan } \\
\text { pribadi saya. }\end{array}$ & 60 & 65 & 6 & 1 & 0 \\
\hline & 2 & $\begin{array}{lrr}\text { Saya lebih } & \text { banyak } \\
\text { mengikuti dan } & \text { menaati } \\
\text { acara tersebut } & \text { daripada } \\
\text { absen } & & \\
\end{array}$ & 38 & 74 & 13 & 6 & 1 \\
\hline & 3 & $\begin{array}{l}\text { Saya mengikuti acara } \\
\text { komunitas tersebut karena } \\
\text { kesadaran pribadi }\end{array}$ & 29 & 70 & 26 & 6 & 1 \\
\hline & 4 & $\begin{array}{l}\text { Saya mengikuti acara } \\
\text { komunitas tersebut karena } \\
\text { keterpaksaan }\end{array}$ & 3 & 10 & 24 & 53 & 42 \\
\hline & & Jumlah & 130 & 219 & 69 & 66 & 44 \\
\hline & & Total & \multicolumn{5}{|c|}{528} \\
\hline
\end{tabular}

\subsubsection{Aturan/Tata Tertib Hidup Bersama}

1. Aturan hidup yang diterapkan di Rumah Bina mendukung perkembangan saya secara pribadi:

\begin{tabular}{|c|c|c|c|c|c|}
\hline SS & S & R & TS & STS & Total \\
\hline 47 & 75 & 10 & 0 & 0 & 132 \\
\hline $35,6 \%$ & $56,8 \%$ & $7,5 \%$ & $0 \%$ & $0 \%$ & $100 \%$ \\
\hline
\end{tabular}




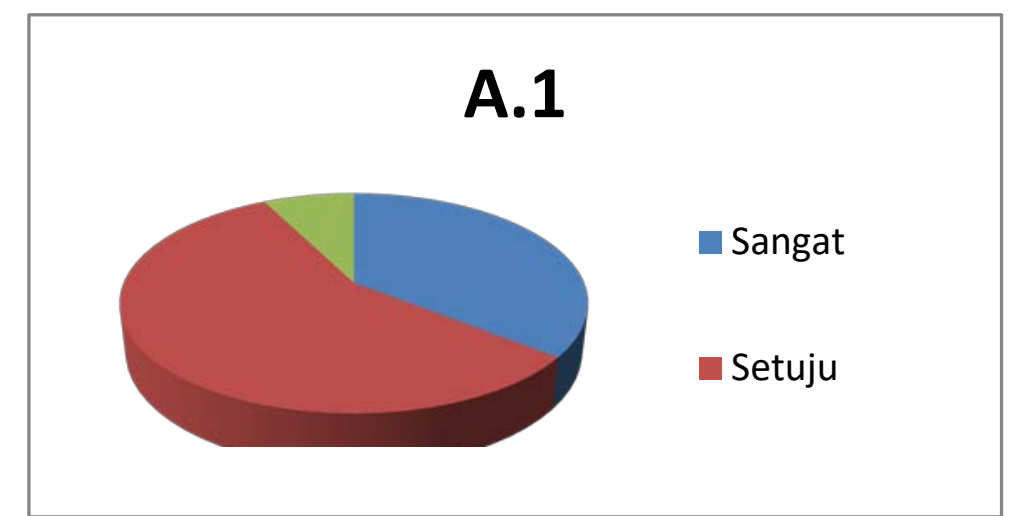

Hasil penelitian menunjukkan bahwa sebagian besar mahasiswa setuju bahwa aturan tata tertib yang dibuat di Rumah Bina mendukung perkembangan pribadi mahasiswa (35,65\% sangat setuju dan 56,85\% setuju). Tidak ada satupun mahasiswa yang tidak mengakui hal ini. Aturan memang dibuat bukan untuk aturan itu sendiri, dan itulah yang terjadi di rumah bina, Tata tertib dan aturan memang ditujukan demi menjaga tertib hidup para mahasiswa.

2. Saya lebih banyak menaati aturan tersebut daripada melanggarnya

\begin{tabular}{|c|c|c|c|c|c|}
\hline SS & S & R & TS & STS & Total \\
\hline 25 & 67 & 29 & 9 & 2 & 132 \\
\hline $18,9 \%$ & $50,7 \%$ & $21,9 \%$ & $6,8 \%$ & $1,5 \%$ & $100 \%$ \\
\hline
\end{tabular}

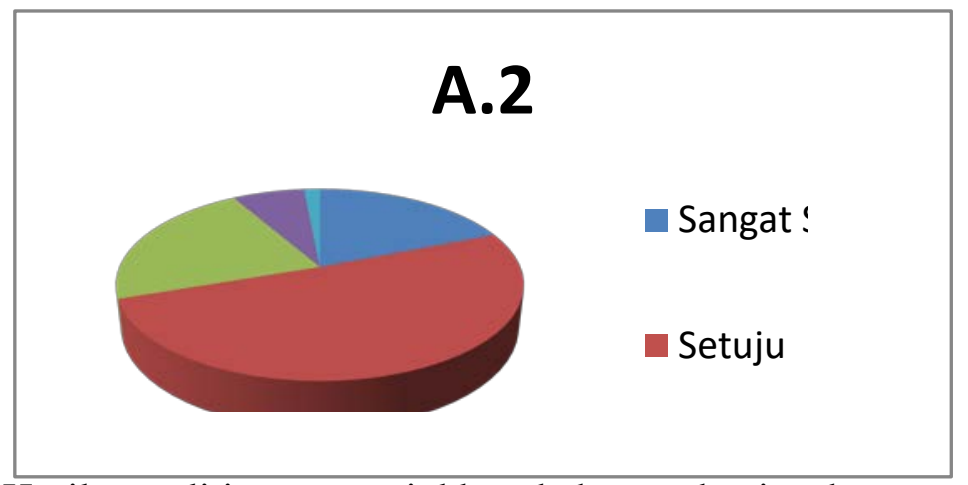

Hasil penelitian menunjukkan bahwa sebagian besar mahasiswa (18,9\% sangat setuju dan 50,7\% setuju) menaati tata tertib tersebut. Ketaatan menjadi hal penting dalam proses pembinaan, dan ternyata sebagian besar mahasiswa mengusahakan diri menjadi orang yang taat. Ada 21,9\% yang mengatakan raguragu artinya mereka ini kadang melakukan pelanggaran juga.

3. Saya menaati aturan tersebut karena kesadaran pribadi

\begin{tabular}{|c|c|c|c|c|c|}
\hline SS & S & R & TS & STS & Total \\
\hline 21 & 72 & 32 & 5 & 2 & 132 \\
\hline $15,9 \%$ & $54,5 \%$ & $24,2 \%$ & $3,7 \%$ & $1,5 \%$ & $100 \%$ \\
\hline
\end{tabular}




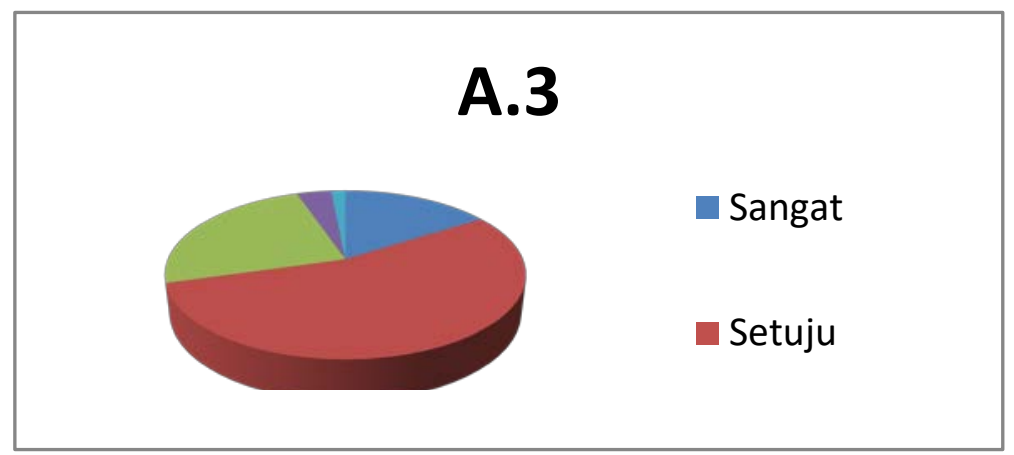

Hasil penelitian menunjukkan bahwa sebagian besar mahasiswa (15,9\% sangat setuju dan 54,5\% setuju) melakukan ketaatan pada tata tertib Rumah Bina karena didasari oleh kesadaran pribadi. Angkanya tidak jauh berbeda dengan jawaban A.2., sehingga mereka yang mempunyai kesadaran cenderung akan menaati aturan. Angka yang ragu (24,2\%) hampir sama dengan jawaban A.2. Hal ini menunjukknan bahwa inkonsistensi kesadaran akan berimbas pada ketidaktaatan juga.

4. Saya menaati aturan tersebut karena keterpaksaan

\begin{tabular}{|c|c|c|c|c|c|}
\hline SS & S & R & TS & STS & Total \\
\hline 2 & 13 & 37 & 52 & 28 & 132 \\
\hline $1,5 \%$ & $9,8 \%$ & $28 \%$ & $39,3 \%$ & $21,2 \%$ & $100 \%$ \\
\hline
\end{tabular}

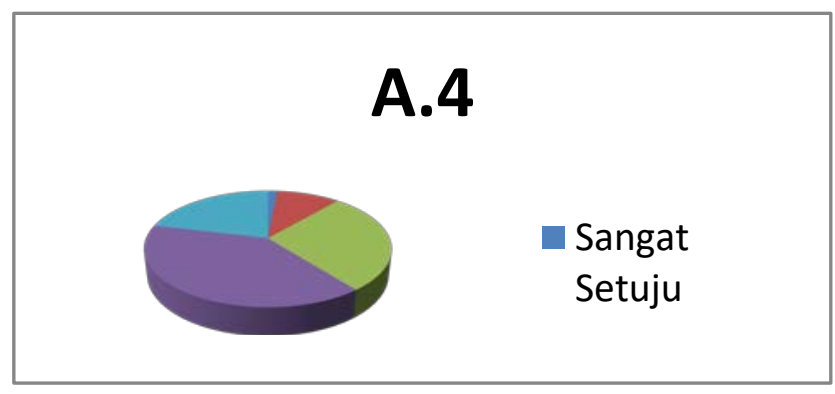

Hasil penelitian meunjukkan bahwa sebagian besar mahasiswa (39,3\% tidak setuju dan 21,2\% sangat tidak setuju) menaati tata tertib bukan karena keterpaksaan. Ada sebagian kecil yang menaati aturan karena terpaksa (1,5\% sangat setuju dan 9,8\% setuju). Angka mahasiswa yang ragu hampir sama dengan pertanyaan A2 dan A3.

\subsubsection{Hidup Rohani}

1. Acara rohani yang diterapkan di Rumah Bina (meditasi, refleksi, bacaan rohani, lectio divina, Rosario, misa, completorium, emaus, dll) mendukung perkembangan saya secara pribadi: 


\begin{tabular}{|c|c|c|c|c|c|}
\hline SS & S & R & TS & STS & Total \\
\hline 64 & 66 & 1 & 1 & 0 & 132 \\
\hline $48,4 \%$ & $50 \%$ & $0,7 \%$ & $0,7 \%$ & $0 \%$ & $100 \%$ \\
\hline
\end{tabular}

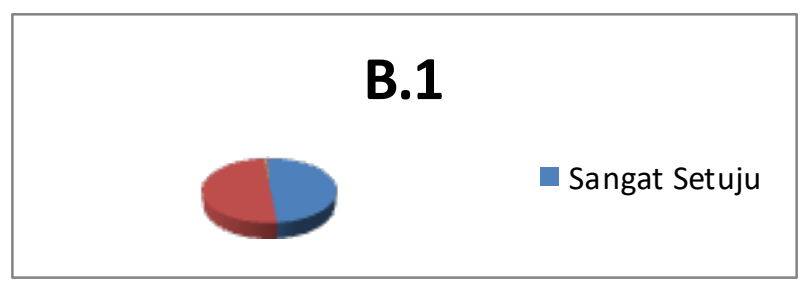

Hasil penelitian menunjukkan bahwa sebagian besar mahasiswa (48,4\% sangat setuju dan 50\% setuju) acara rohani di Rumah Bina berpengaruh positif pada perkembangan rohani mahasiswa. Angka yang meragukan atau menolak hal tersebut bahkan sangat kecil jumlahnya.

2. Saya lebih banyak menaati aturan tersebut daripada melanggarnya

\begin{tabular}{|c|c|c|c|c|c|}
\hline SS & S & R & TS & STS & Total \\
\hline 38 & 74 & 13 & 6 & 1 & 132 \\
\hline $28,7 \%$ & $56 \%$ & $9,8 \%$ & $4,5 \%$ & $0,7 \%$ & $100 \%$ \\
\hline
\end{tabular}

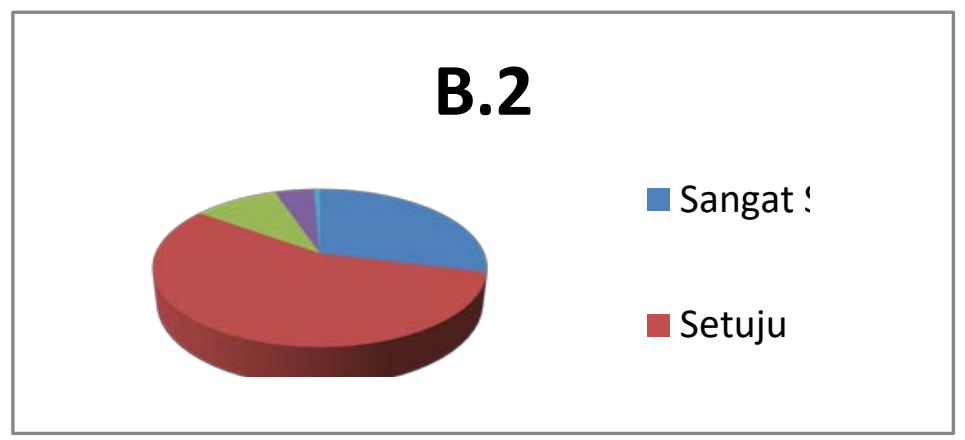

Ketaatan akan tertib hidup rohani merupakan pondasi bagi formatio katekis dan guru agama. Sebagian besar mahasiswa (28,7\% sangat setuju dan 56\% setuju) mengatakan bahwa mereka lebih banyak menaati aturan tersebut, dan sangat sedikit (4,5\% tidak setuju dan 0,7\% sangat setuju) yang melanggarnya.

3. Saya menaati aturan tersebut karena kesadaran pribadi

\begin{tabular}{|c|c|c|c|c|c|}
\hline SS & S & R & TS & STS & Total \\
\hline 32 & 76 & 21 & 3 & 0 & 132 \\
\hline $24,2 \%$ & $57,5 \%$ & $15,9 \%$ & $2,2 \%$ & $0 \%$ & $100 \%$ \\
\hline
\end{tabular}




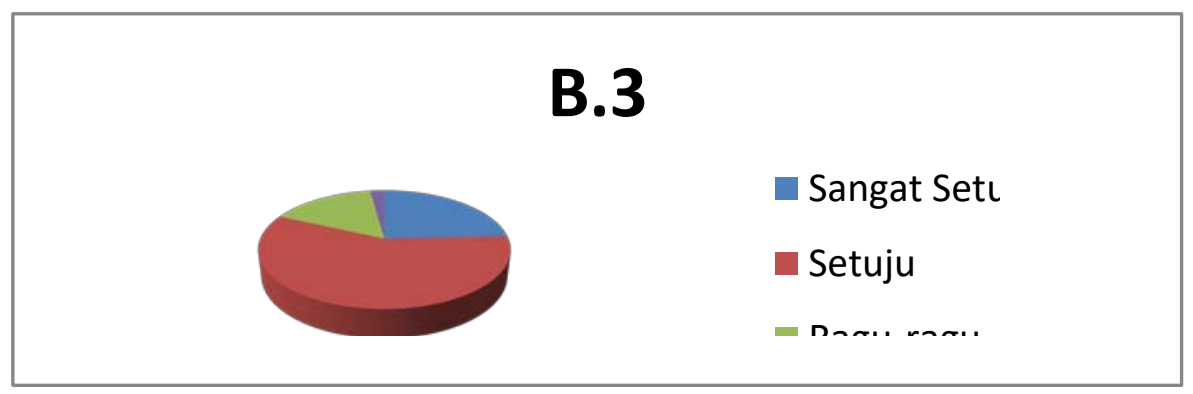

Sebagian besar mahasiswa mengatakan bahwa mereka menaati hal tersebut karena kesadaran pribadi (24,2\% sangat setuju dan 57\% setuju). Kesadaran pribadi memang amat diperlukan untuk membangun hidup rohani yang baik. Menarik untuk mencermati angka 15,9\% keragu-ragan, yang meskipun kecil tetapi harus mendapat perhatian. Jika merujuk pada hasil B2, angka 15,9\% adalah gabungan mereka yang mengatakan ragu dan menolak dalam hal ketaatan pada acara rohani pada pertanyaan sebelumnya. Ketidaktaatan berkorelasi langsung pada kesadaran pribadi. Semakin orang sadar akan pentingnya hidup rohani, maka lebih mudah untuk menjadi taat.

4. Saya menaati aturan tersebut karena keterpaksaan

\begin{tabular}{|c|c|c|c|c|c|}
\hline SS & S & R & TS & STS & Total \\
\hline 1 & 9 & 17 & 57 & 48 & 132 \\
\hline $0,7 \%$ & $6,8 \%$ & $12,8 \%$ & $43,1 \%$ & $36,3 \%$ & $100 \%$ \\
\hline
\end{tabular}

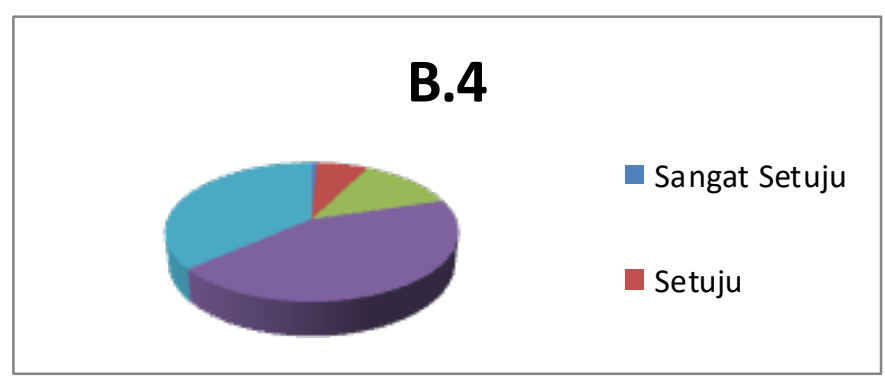

Data menunjukkan bahwa sebagian besar mahasiswa mengikuti acara rohani di Rumah Bina bukan karena keterpakasaan (34\% tidak setuju dan 36\% sangat tidak setuju). Angka ini juga berbanding lurus dengan pertanyaan sebelumnya mengenai ketaatan dan kesadaran pribadi. Angka dari mereka yang terpaksa dalam mengikuti acara rohani juga berbanding lurus dengan pertanyaan sebelumnya mengenai ketidaktaatan dan ketidaksadaran. 


\subsubsection{Acara Komunitas}

1. Acara komunitas (wicara, sidang akademi, rekreasi, opera, konferensi, dinamika kelompok, paduan suara, bahasa inggris, studi, dll) mendukung perkembangan pribadi saya:

\begin{tabular}{|c|c|c|c|c|c|}
\hline SS & S & R & TS & STS & Total \\
\hline 60 & 65 & 6 & 1 & 0 & 132 \\
\hline 45,4 & $49,2 \%$ & $4,5 \%$ & $0,7 \%$ & $0 \%$ & $100 \%$ \\
\hline
\end{tabular}

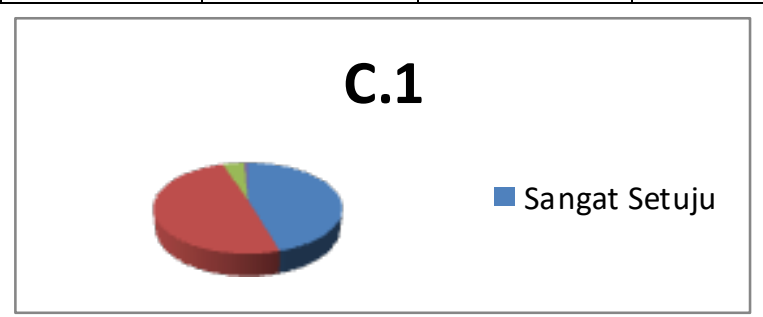

Hasil penelitian menunjukkan bahwa sebagian besar mahasiswa $(45,4 \%$ sangat setuju dan 49,2\% setuju) acara komunitas di Rumah Bina berpengaruh positif pada perkembangan rohani mahasiswa. Angka yang meragukan atau menolak hal tersebut bahkan sangat kecil.

2. Saya lebih banyak mengikuti dan menaati acara komunitas tersebut daripada absen.

\begin{tabular}{|c|c|c|c|c|c|}
\hline SS & S & R & TS & STS & Total \\
\hline 48 & 75 & 6 & 3 & 0 & 132 \\
\hline $36,3 \%$ & $56,8 \%$ & $4,5 \%$ & $2,2 \%$ & $0 \%$ & $100 \%$ \\
\hline
\end{tabular}

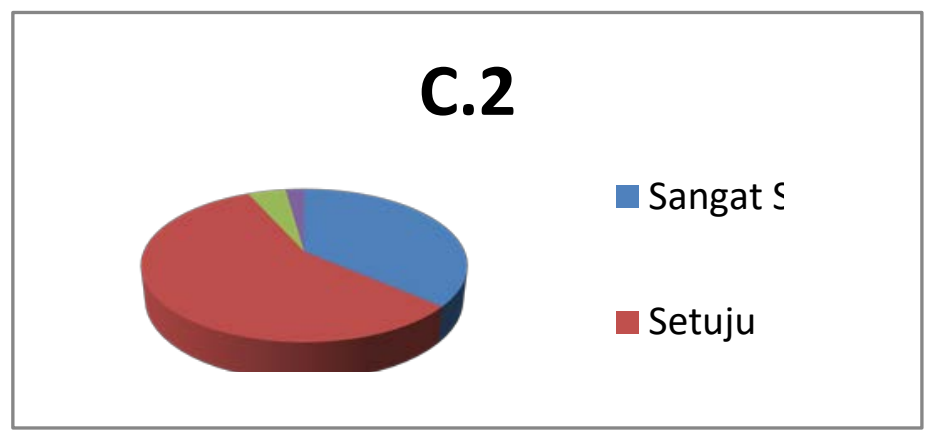

Sebagian besar mahasiswa (36,3\% sangat setuju dan 56,8\% setuju) mengatakan bahwa mereka lebih banyak mengikuti acara komunitas, dan sangat sedikit (2,2\% tidak setuju) yang absen.

3. Saya mengikuti acara komunitas tersebut karena kesadaran pribadi

\begin{tabular}{|c|c|c|c|c|c|}
\hline SS & S & R & TS & STS & Total \\
\hline 29 & 70 & 26 & 6 & 1 & 132 \\
\hline $21,9 \%$ & $53 \%$ & $19,6 \%$ & $4,5 \%$ & $0,7 \%$ & $100 \%$ \\
\hline
\end{tabular}




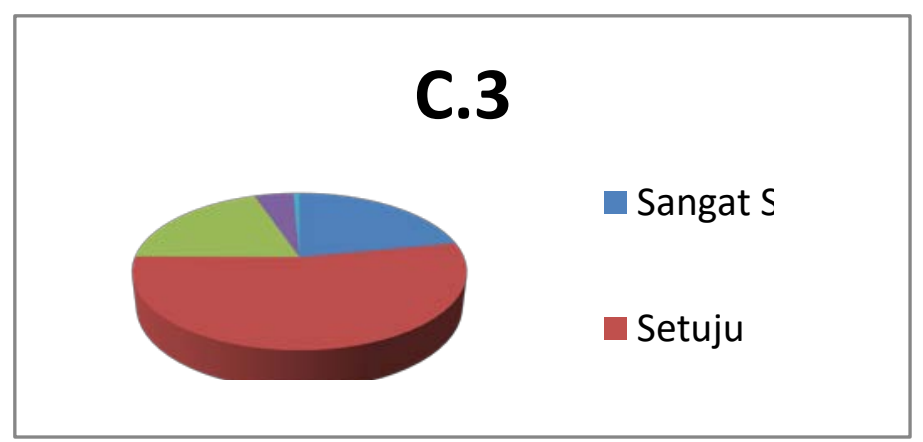

Sebagian besar mahasiswa mengatakan bahwa mereka mengikuti acara komunitas tersebut karena kesadaran pribadi (21,9\% sangat setuju dan 53\% setuju). Kesadaran pribadi untuk membenruk diri dalam acara harian memang amat diperlukan untuk membangun kebiasaan yang baik. Menarik untuk mencermati angka 19,6\% keragu-raguan, yang meskipun kecil tetapi harus mendapat perhatian, dan ini konsisten pada pertanyaan berikutnya ketika menjawab soal keterpaksaan.

4. Saya mengikuti acara komunitas tersebut karena keterpaksaan

\begin{tabular}{|c|c|c|c|c|c|}
\hline SS & S & R & TS & STS & Total \\
\hline 3 & 10 & 24 & 53 & 42 & 132 \\
\hline $2,2 \%$ & $7,5 \%$ & $18,1 \%$ & $40,1 \%$ & $31,8 \%$ & $100 \%$ \\
\hline
\end{tabular}

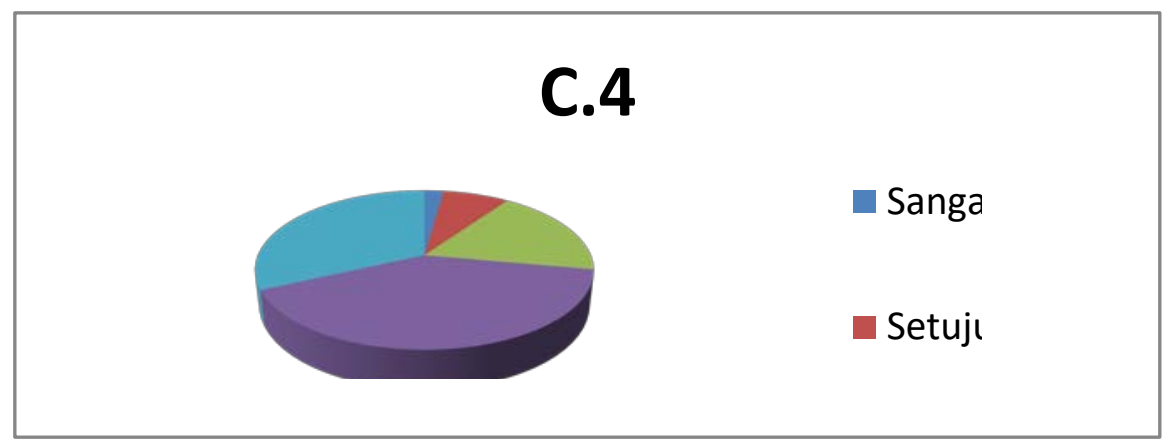

Data menunjukkan bahwa sebagian besar mahasiswa mengikuti acara komunitas di Rumah Bina bukan karena keterpakasaan (40,1\% tidak setuju dan $31,8 \%$ sangat tidak setuju). Angka ini juga berbanding lurus dengan pertanyaan sebelumnya mengenai ketaatan dan kesadaran pribadi. Angka dari mereka yang ragu-ragu jua konsisten dengan pertanyaan sebelumnya.

\subsection{Analisa dan Narasi}

Penelitian ini dilakukan di akhir masa pendidikan di Rumah Bina. Penelitian ini dengan demikian dilakukan setelah mereka menjalani proses bina selama satu tahun. Para responden dalam hal ini sudah mengalami proses bina dan akrab dengan segala tata tertib, acara rohani, dan acara komunitas di Rumah Bina. 
Hal tersebut menjadi bekal yang cukup untuk menjawab aneka pertanyaan yang diajukan.

Hasil penelitian menunjukkan bahwa hampir sebagian besar mahasiswa memahami pentingnya aturan dalam hidup bersama, hidup rohani, dan hidup komunitas dalam formation bersama. Ada cukup banyak mahasiswa yang mengalami formatio di Rumah Bina. Aturan dalam hidup bersama dibutuhkan untuk menjaga tertib hidup bersama di Rumah Bina. Syukurlah mayoritas responden menyadari pentingnya aturan hidup bersama, pentingnya acara rohani untuk membina spiritualitas mereka, dan perlunya acara komunitas untuk menanamkan kebiasaan yang baik.

Tata tertib, acara rohani, dan acara komunitas menjadi pondasi yang dibutuhkan untuk formatio bersama. Syukurlah, sangat sedikit responden yang menolak dan melanggarnya. Hal ini tampak dari hasil penelitian di atas.

Ketaatan pada aturan, acara rohani, dan acara komunitas kemudian menjadi elemen berikutnya yang harus ditanamkan dalam proses formatio. Hasil penelitian menunjukkan bahwa mayoritas mahasiswa memilki kesadaran tersebut. Tata tertib, acara rohani, dan acara komunitas diikuti dengan penuh kesadaran. Ada sangat sedikit dari mereka yang ragu-ragu ataupun melanggarnya.

Angka keraguan ini berbanding lurus dengan angka keterpaksaan. Ada sedikit mahasiswa yang mengikuti acara komunitas, tata tertib, dan acara rohani dengan keterpaksaan. Meskipun angkanya sedikit, mereka ini harus mendapat perhatian dalam proses formatio, karena ternyata internalisasi nilai-nilai belum terjadi pada mereka meskipun sudah sekian lama menjalani proses bina. Hal ini akan membahayakan pada jenjang pembinaan selanjutnya. Ketaatan dan kesadaran pribadi menjadi elemen mutlak yang secara intrinsik harus dimiliki mahasiswa dalam proses bina menjadi katekis dan guru agama. Jika segala sesuatu dikerjakan secara terpaksa dan tanpa kesadaran pribadi, maka sebenarnya diperlukan formatio lanjutan untuk mahasiswa seperti ini.

\section{KESIMPULAN}

Sebagai rekan kerja pastor kelak, para calon katekis dan guru agama memang harus dibentuk secara khusus. Pembentukan kader Gereja memang memerlukan satu tempat penggodokan khusus (asrama) sebagaimana layaknya Akmil, Akpol, dll. Rumah Bina adalah salah satu ikhtiar untuk itu, meskipun harus diakui masih banyak kekurangan di sana-sini.

Mahasiswa yang tidak semuanya mempunyai motivasi yang tinggi dalam menjadi calon pewarta sabda, kendala ekonomi, dan tempat asal yang jauh tertinggal menjadi kendala tersendiri dalam melakukan formatio. Idealnya para mahasiswa tidak hanya menjalani proses formatio selama setahun, akan tetapi banyak faktor yang membuat pembinaan wajib hanya bisa dijalankan satu tahun. 
Keputusan minus malum harus diambil, dari pada tidak membekali mereka sama sekali. Kedepan mungkin perlu dipikirkan untuk memperluas cakupan tingkat supaya para mahasiswa menjalani pembinaan dan bisa menginternalisasi nilainilai yang diberikan dengan lebih baik.

Forrmatio yang sudah dijalankan selama ini sebaiknya terus dijalankan. Hasil penelitian menunjukan bahwa sebagian besar mahasiswa menanggapi baik sistem formation selama ini. Kelemahan yang masih ada bisa dijadikan bahan evaluasi untuk perbaikan selanjutnya demi membentuk para calon pewarta sabda yang tangguh di masa depan.

\section{DAFTAR PUSTAKA}

Dewantara, A. W. 2015. "Filosofi Pendidikan yang Integral dan Humanis dalam Perspektif Mangunwijaya” dalam JPAK: Jurnal Pendidikan Agama Katolik. 13(7), 3-9.

Dewantara, A. W., \& Permana, N. S. 2018. "Peneleitian terhadap Minat menjadi Guru Agama dan Katekis di STKIP Widya Yuwana Madiun” dalam JPAK: Jurnal Pendidikan Agama Katolik. 19(10), 39-49

Dewantara, A, W. 2019. "Pendidikan Nilai Gotong-Royong Sebagai Strategi Ketahanan Nasional” dalam Jurnal Civis

Dwilestari, A., \& Dewantara, A. W. 2019. "Pengaruh Penggunaan Facebook bagi Kehidupan Rohani Mahasiswa STKIP Widya Yuwana” dalam JPAK: Jurnal Pendidikan Agama Katolik. 19(2), 28-43

Hardjana, Agus M. 2005. Religiusitas Agama dan Spiritualitas. Yogyakarta: Kanisius

Masaong.2000. Spirituality. Oxford

Nilam, W. 2009. Kunci Pengembangan Diri. Jakarta: Elex Media Komputindo

Juna, M., \& Dewantara, A. W. 2018. "Makna dan Penghayatan Sakramen Ekaristi Bagi Calon Katekis” dalam JPAK: Jurnal Pendidikan Agama Katolik. 20(10). 133-143

Rumah Bina Karya Illahi. 2018. Buku Pedoman Hidup Bersama. Madiun

STKIP Widya Yuwana. 2009. Pedoman Mahasiswa STKIP Widya Yuwana. Madiun

Tarigan, Jacobus., 2015, Religiositas dan Gereja Katolik. Yogyakarta: Kanisius Tondowidjojo. 2012. Santo Vincentius de Paul. Surabaya: Sanggar Bina Tama Zohar dan Marshal. 2005. Spiritual Capital. University Press 